\title{
Italian Civil Justice Reform 2009
}

\section{Prof. Dr. Remo Caponi, Florenz}

1. Introduction

2. Mediation

3. New summary proceedings

4. Reform of the civil proceedings before the Court of Cassation

5. Introduction of a general norm on cocrcive measures

6. Innovations on the right to be heard

7. Codification of the principle of non-bjoj tivil (non contestazione)

8. Introduction of a general norm on of time limits (rimessione in termini)

\section{Introduction}

The Italian Civil Justice Reform 2009 (Law no. 69 of $18^{\text {th }}$ June, 2009 and, based on this law, Legislative Decree no. 28 of $4^{\text {th }}$ March, 2010) has amended several provisions of the Code of Civil Procedure (CCP), but it has left untouched the root causes of inefficiency of the Italian civil justice system.

The causes of the unreasonable length of civil proceedings in Italy are many. There are too few judges in relation to the number of disputes to resolve. Many judicial districts are too small and should be merged. The judges are not assisted by law clerks in the preparation of their decisions. Judges often do not even have their own room to work. The presidents of the courts are appointed by the Supreme Council of the Judiciary (Consiglio Superiore della Magistratura) which of ten takes no account of their managerial skills. The number of court clerks is insufficent to cover the needs. Finally, e-justice still remains very marginal.

None of these problems has been addressed by the 2009 reform. There is a need for political will, and human and material resources, which are not there. Therefore, we are satisfied with the modification of only the written words in the law's text.

In this paper I do not examine all the innovations of the 2009 reform, but only the most important/

\section{Mediation}

The Legislative Decree no. 28 of $4^{\text {th }}$ March 2010 implements the Directive 2008/52/ EC of the European Parliament and of the Council of $21^{\text {st }}$ May 2008 on certain aspects of mediation in civil and commercial matters. All the aspects covered by the Directive are transposed: judicial mediation, enforceability of an agreement resulting from mediation, confidentiality, and the effect of mediation on limitation and prescription periods.

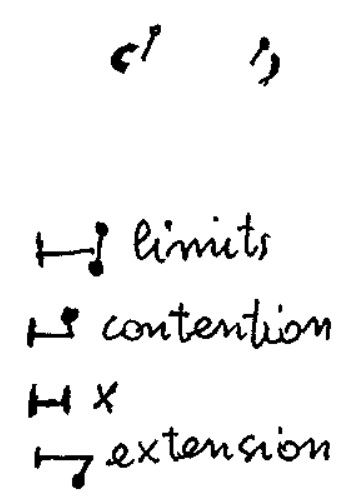

ones. 
Caponi, Italian Civil Justice Reform 2009

The new rules apply not only to cross-border disputes, but also to internal disputes.

Before listing the main aspects of the new rules on mediation, I shall make some general remarks.

When the movement for alternative dispute resolution (ADR) was adopted in Ita$\mathrm{ly}$, it was stressed from the outset that these alternatives have an added value in relation to the civil justice system, even when the latter functions efficiently. Alternative dispute resolutions constitute an aspect of the access to justice, from the perspective opened up by the great project of Mauro Cappelletti in the $1970 \mathrm{~s}^{1}$.

The movement for access to justice is characterised by three 'waves'. The first wave consists of the development of mechanisms for providing legal aid. The second wave is directed to organise class actions against illegal acts affecting many people. ${ }^{2}$ The third wave is driven precisely by the simplification of proceedings and the development of alternative methods of dispute resolution.

Only the harmonic and proportionate combination of the three waves can efficiently respond to the demand for justice from society. For this reason the promotion of mediation should always be accompanied by efforts to improve the efficiency of the civil justice system. certain categories of disputes are better suited than others to be resolved through mediation. Let's consider a few examples.

One category is where the parties are members of a group or maintain a long-term social or economic relationship. The civil process is intended to ascertain the past and, as a rule, does not take into account the future. For this reason it often results in a conclusive breakup between the parties. Instead, mediation can broaden the perspective and help maintain future relations between the parties. This is the perspective of situational justice, already adopted ante litteram in the Italian Civil Code of 1942 (Article 1965, par. 2, CC).

Another category is that of small claims, often those of consumers. In these cases the average length of the civil procedure and the lawyer's fees are disproportionate in relation to the small value of the dispute. So the consumer of ten does not claim his right before the courts. Mediation is an alternative that costs less than the civil procedure.

Frequently, consumers injured by an illegal act are many and fall into a class. When there are questions of law or facts at stake which are common to the class, and the claims are typical, the most efficient solution is not an individual mediation but a class action eventually followed by a collective mediation.

If there are many people injured, but the damages suffered by each individual are an individual judicial lawsuit is certainly not advisable; neither is an individual

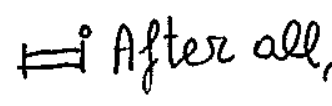

1 See M. Cappelletti $\&$ B. Garth, Access to justice: The Worldwide Movement to make Rights Effective. A General Report, 1, 1, Milan and Alphenaandenrijn, 1978-79, 3; V. Varano, Presentazione a L'altra giustizia. I metodi alternativi di soluzione delle controversie nel diritto comparato, V. Varano (ed.), Milan, 2007, IX.

2 See Art. 140-bis Consumer Code (2009 version). 
Caponi, Italian Civil Justice Reform 2009

mediation. Instead a 'collective redress action' is more convenient (Article 140-bis, Consumer Code). The latter costs the individual consumer less time and money than the individual mediation. The class action, then, encourages consumers to claim their rights.

However, if the costs for the recovery are greater than the value of the sum to be recovered (when this is really very small), it is preferable to confiscate the profits of the company through the application of an administrative fine equal to the value of profit unlawfully obtained (so called 'skim off').

In addition, collective redress actions organise a collective response by the consumers against the company's wrongdoing. Therefore this reaction has a deterrent effect against the company which is much greater than that of a consumer's individual lawsuit.

The existence of collective redress action also serves to improve the functioning of mediation because it strengthens the position of the weaker party, the consumer. $\mathrm{He}$ can refuse to enter into an unfair agreement because he knows that an effective remedy is available before the courts.

As well as a means of access to justice, in Italy mediation has also been promoted as a means to reduce the courts' workload.

The 2009 reform also takes into account this second function of mediation. Indeed it provides for mandatory mediation before the commencement of the proceedings in a significant number of disputes: not only for those where the parties are members of a group or maintain a long-term social or economic relationship, but also for those in which the parties meet (or better, collide) for the first time because of the dispute (for example, in case of damages from car accident). Courts may enforce mandatory mediation by ordering the stay of the proceedings in cases where mediation has not been sought before the commencement of the proceedings.

Many commentators criticise the provisions requiring mediation to be sought compulsorily. They observe that mediation is possible only if both parties are willing to discuss their dispute, to examine the merits of their position in good faith, and ultimately to consider reaching a compromise solution.

While this viewpoint is undoubtedly accurate, it is worth mentioning the other side of the coin. Often the parties are not aware of the costs of the process before the courts and of the considerable length of civil procecdings. Moreover, the parties frequently do not even know that there is the possibility of making use of mediation. The provision of mandatory mediation can spread awareness of alternative methods of dispute resolution and thus propel the willingness of the parties to make use of them to solve their disputes.

The courts can instruct litigants during the proceeding to pursue mediation (mediazione delegata or judicial mediation).

The bar associations may arrange the court-annexed-mediation at the courts of first instance (tribunali), but also available are the mediations run by the chambers of commerce and other professional associations (out-of-court-mediation).

During mediation, confidential communications are privileged against compulsory production in legal proceedings. 


\section{Caponi, Italian Civil Justice Reform 2009}

A still unsolved problem is the training of professional mediators. The rules currently in force provide that those interested in carrying out this profession should attend training courses of only thirty-two-hour lessons. It is doubtful that these courses provide adequate preparation. The government has pledged the enactment of new regulation on this issue shortly, which is one of the most important aspects for the success of mediation.

The government has a strong interest in promoting mediation because it is less expensive than civil litigation. For this reason, the legislation provides tax benefits in relation to mediation and conciliation agreements.

To sum up, the new rules on mediation are not a panacea for the inefficiency of the Italian civil justice system, but they are certainly a step in the right direction.

\section{New summary proceedings}

Law no. 69 of 2009 has introduced a new summary proceeding in the Fourth Book of the Code of Civil Procedure: procedimento sommario di cognizione (Art. 702-bis, ter, -quater, CCP)?

The new summary proceeding applies to cases where the court decides at first instance as a single judge.

The proceeding may have as its purpose an action for coercive relief (azione di condanna), an action for declaratory judgment (azione di mero accertamento) or an action to create, modify or extinguish a legal relationship between the parties (azione costitutiva).

Except for the claim form (ricorso), the determination of the date of the hearing by the court and the shorter terms to appear before it, the regulation of the introductory stage is based on that of the ordinary proceeding. The ricorso must contain the same elements of the citazione (the claim form in the ordinary proceeding). This in turn must be served the defendant (by the plaintiff) at least forty days before the date fixed for the hearing. The defendant must file his appearance at least ten days before the hearing. Within this term the following are subject to preclusion: the proposition of procedural objections or objections on the merits of the case which may be raised only by the parties, the bringing of counterclaims and the joining of a third party.

At the hearing, the court must determine whether to continue to consider the case according to the summary proceeding or, instead, to follow the ordinary proceeding, if it considers that the arguments presented by the parties require a 'non-summary proceeding' (Article 702-ter, par. 3 CCP), namely, if the treatment of the case is not simple. In the latter case, the court fixes the hearing according to Art. 183, CCP. The preclusions already gained cannot be reviewed, but the court may grant relief from the effects of the expiration of time (rimessione in termini).

If the court continues to handle the case according to the summary proceeding, 'after hearing the parties, omitting any formality which is not indispensable for complying with the right of the parties to be heard, it proceeds in the way it deems more proper to accomplish the evidentiary acts which are relevant in relation to the object of the requested decision' (Art. 702-ter, par. 5), namely, in relation to the determina-
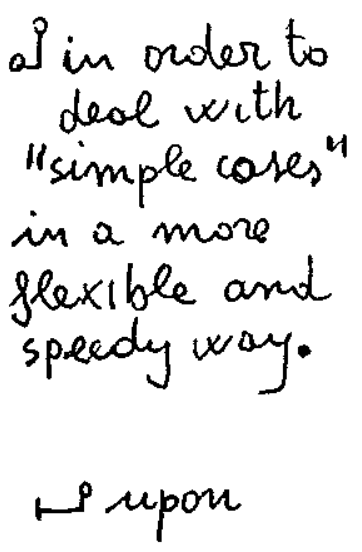
tion of the right claimed before the court. The regulation of the evidentiary stage is not entrusted to the law, but is entrusted to the discretionary powers of the court, subject to compliance with the constitutional right to be heard.

On the merits, the summary proceeding ends with a decision that contains an order granting or denying the relief. If granted, the judgment (when it has content of coercive relief) is provisionally enforceable, and constitutes entitlement for the inscription of a judicial mortgage as well as for the registration in the land registry. If it is not appealed within thirty days of its communication or notification, the judgment becomes res judicata.

The appeal proceeding follows the rules of the ordinary proceeding in terms of the formalities (therefore it should be proposed by citazione). New means of evidence and new documents are admitted when the Court of Appeal considers them relevant to decide the case, or when the party proves that he could not offer them during the first instance due to a fortuitous event.

The idea that is prevailing, in the first few decisions by the courts, is that, despite its name, the summary proceeding is actually a special full evidentiary process, simplified compared to the ordinary one, deemed to deal with 'simple' cases. In fact, the 'labels' never bind the interpreter in the reconstruction of the content of the norms. Moreover, the Code of Civil Procedure of 1865 labeled as summary a full evidentiary proceeding which was an alternative to the formal (non-summary) one.

In fact, the history of civil justice shows that the summary proceedings are designed to meet specific needs: namely, procedural economy (in cases where it is likely that the counterparty will not defend his position), the need to proceed with urgency to neutralise a periculum in mora (i. e. the danger of suffering a damage unsuitable of adequate compensation), and the aim of preventing the abuse of the right of defence.

However, the new summary proceeding does not have these goals. In fact, with regard to its scope and consequently the requirements of the decision granting the application, the new summary proceeding is quite atypical. Its scope covers all the cases brought before the court at first instance as a single judge. As for the type of actions that can be brought, it coincides with the ordinary one. With regard to the characteristics of the evidentiary activity, the court is called upon to perform sic et simpliciter the evidentiary acts relevant to the determination of the right, in accordance with the constitutional right to be heard. In relation to the stability of the final decision, it is res judicata. Finally, when delegating to the government the enactment of the legislative decree aimed at rationalising and simplifying civil proceedings, Art. 54, par. 4, Law no. 69/2009, stipulates that the new summary proceeding applies to 'procedures, even those before the chamber of council (camera di consiglio), where there is a prevailing disposition towards the simplification of the treatment of the case' (but the possibility of converting such proceedings to ordinary procedure is excluded).

The regulation of the new summary proceeding lends itself to various criticisms. The main critical aspect is the following. The court cannot order the transfer of a case from the ordinary proceeding (initiated by the plaintiff in a simple case) to the summary one. This rigidity can be explained if one assumes that the ordinary and the 
Caponi, Italian Civil Justice Reform 2009

summary proceedings 'dwell' in completely different worlds. On the other hand, it cannot be explained (and it is irrational) if one starts from the idea that it is a choice between two 'track/, both of them being full evidentiary proceedings.

This defect can be partly overcome through agreements between lawyers and judges, such as the protocols prepared by the 'observatories of the civil justice' (osservatori sulla giustizia civile). These agreements should have as the main objective the identification of the categories of simple cases that can be dealt with through summary proceedings. This operation should exert a persuasive effect in relation to practitioners, to facilitate the introduction of such cases through the summary proceeding, and in relation to the judge, to avoid a hasty transfer to the ordinary 'track'.

To sum up, the characteristic of the summary proceeding is to be a legislative 'cover' doomed to be modeled on the concrete workload of the courts and to be a receptive model of the best practices, agreed between practitioners and the judiciary. Because of many causes and difficult conditions, it can fail in many court rooms, but perhaps not in all of them, and then it will be worth it, while we await for better times and means for the civil justice.

Moreover, we cannot hide that the argument just developed constitutes an ex post rationalization of a choice by the legislator who was not fully aware of all its implications. Looking ahead, the best choice is to restructure the ordinary proceeding, by dividing it into two legislatively predetermined tracks, entrusted to the discretion of the court in collaboration with the parties, and based on the complexity of the individual case.

\section{Reform of the civil proceedings before the Court of Cassation}

Italy is a country where the gap between what is said and what is done is remarkable, and so is the gap between declarations of intent and actual willingness and ability to achieve them.

In the context of the Italian civil justice system, one of the major gaps between law in the books and law in action can be observed in relation to the difference between legislative provisions on the scope of the review by the Court of Cassation (Corte di Cassazione) and the way in which the Court of Cassation operates in practice.

Since 1923, there is only one Supreme Court of Cassation which has its seat in Rome. Previously there were five regional courts of cassation (in Turin, Florence, Rome, Naples and Palermo), that survived the unification of Italy in the $19^{\text {th }}$ century.

Within the civil division of the Court of Cassation, there are currently about one hundred and forty magistrates (to which should be added twenty five presidents, who almost never write the judgments).

According to the slightly rhetorical wording of Art. 65 of the Judiciary Act (Royal Decree no. 12 of 1941), the task of the Court of Cassation is to ensure 'the strict observance and uniform interpretation of the law'. In the Italian legal culture this function is known as nomofilachia and differs from the function to provide the party who lost a remedy to check the validity and justice of the judgment. 
Nomofilacbia is constitutionally relevant because it is an aspect of the principle of equality (Art. 3 of the Constitution). In a system like the Italian one, where the law is usually formulated in general and abstract rules, it can happen that different judges, when applying often ambiguous and contradictory provisions, adopt conflicting decisions in similar cases, based on different interpretations of the same provision.

In this context, the function of the Court of Cassation concerns the development and improvement of the law applicable not only to the dispute in question, but also to future ones, so that among the various possible interpretations of the same act one prevails over the others. This is because of the authority and prestige of the body which adopts this specific interpretation. The prerogative of the Court of Cassation to state 'in the interest of the law, the principle of law' (principio di diritto nell'interesse della legge) with a decision that has no effect on the dispute in question, but only for the future (Art. 363, CCP) is significant from a theoretical point of view.

When deciding the review, the Court of Cassation establishes an interpretation that must have a persuasive and exemplary value for all the courts. This effect emanates from the principle or rule stated by the Court when deciding on the particular dispute.

However, if after considering this theoretical point of view we examine the actual developments subsequent to the codification of 1942, a completely different picture emerges.

The number of reviews brought before the Court of Cassation each year since 1946 has been almost always higher than the number of reviews decided. Thus, the number of pending cases have gradually increased to a hundred thousand.

Furthermore, in its present organisation, the Court of Cassation is divided into six divisions. Each judge writes over two hundred and forty decisions every year and the Court as a whole issues about thirty thousand decisions each year. In these circumstances, the Court cannot accomplish the task of ensuring the uniformity of the law. Instead of being a source of guidance, the Court is often a source of confusion for lower courts, partly because of the inevitable vagueness with which most of its decisions are written. This encourages the increase in the number of reviews because there is always the hope that they will meet a favourable decision, possibly due to the Court being distracted or due to a conscious revirement.

The proceeding before the Court of Cassation lasts an average of more than two years.

To complete the picture, it should be noted that the number of lawyers admitted to plead before the Court of Cassation is exorbitantly large and far exceeds thirty thousand.

This situation requires a drastic intervention aimed at introducing, through a statutory provision, a mechanism to select the applications to be admitted for a Court of Cassation decision on the merits, since the task entrusted to it cannot be pursued without a significant reduction of its workload. Indeed, any organisational effort without such legislative intervention will never be able to resolve the difficult situation in which the Court of Cassation and its judges are now forced to work. 
Caponi, Italian Civil Justice Reform 2009

The legislative reform aimed at introducing this 'filter' in the access to the Court of Cassation must be considered together with the constitutional right of review before the Court: Art. 111, par. 7 of the Constitution provides that review of judgments contrary to law should always be admitted before the Court of Cassation.

This constitutional norm, which had been subject to an attempted amendment in the context of a failed constitutional reform in the late $1990 \mathrm{~s}$, has been an obstacle to the introduction of a legislative mechanism for the selection of reviews. Therefore, efforts were made in order to speed up the proceeding before the Court of Cassation through various tricks. First, the provision of a simplified proceeding in chambers that is, without a hearing - for decisions on applications which are inadmissible, manifestly untounded or manifestly grounded (Arts. 375 and 380-bis, CCP). Second, the provision of the burden on the applicant to 'illustrate' the motives of the application with a 'question of law', (quesito di diritto) under penalty of dismissal of the application. This is what is mandated by Art. 366-bis, CCP, introduced in 2006 and abolished in 2009 to make way for a new mechanism to reduce the workload of the Court of Cassation: Art. 360-bis, CCP.

Article $360-$ bis CCP consists of two paragraphs. Number 1 Ystipulates that the review is inadmissible 'when the challenged decision has decided the issues of law consistently with the jurisprudence of the Court, and the exam of the grounds (of the application) does not offer elements to confirm or amend the same opinion'. The new rule does not lead to any radical change, as it only deems as inadmissible what was qualified as manifestly ungrounded before, with the only significant consequence of annuling late cross-reviews (appello incidentale tardivo). Number 2 states that the review is inadmissible 'when the challenge concerning the breach of principles governing the due process is manifestly groundless'. Some authors have inferred from this provision a narrowing of the motives for reviews pursuant Art. 360, par. 4, CCP, 'for nullity of the judgment or of the proceeding'. In fact, number 2 is devoid of any innovation as well, since all the procedural defects censurable under Art. 360, par. 4 , CCP, determine the violation of the due process.

While awaiting the first jurisprudence of the Court of Cassation in this matter, we should conclude that Law 69 of 2009 leaves essentially unchanged the regulation of the reviews proceeding before the Court of Cassation as well as the problems related to it.

\section{Introduction of a general norm on coercive measures}

Article 614-bis, CCP, introduces an atypical system of coercive measures aimed at ensuring the enforcement of judgments for coercive relief related to obligations to be performed by the debtor in person (i. e. obligations which cannot be performed by a third party: obblighi infungibili). Law 69 of 2009 thus fills a significant gap in the legislation, criticised since the early decades of the $20^{\text {th }}$ century. The norm provides that the court may order the obliged party to pay a sum of money 'for any breach or next non-observance', and thus it basically adopts the French model of astreintes.

However, the new regulation presents a number of drawbacks: 
Caponi, Italian Civil Justice Reform 2009

(a) it estipulates that the coercive measures shall be ordered (after being requested by the parties), and their amount determined, by the court at the time that the decision is made; and not by the court in charge of the execution. This last option would have been more appropriate in order to better adapt the amount of the coercive measure to the degree and quality of the non-fulfilment.

(b) instead of stipulating a general rule that coercive measures cannot be imposed to ensure the fulfilment of obligations derived from a work contract in case of selfemployment or dependent employment (to safeguard the personal freedom), the law bestows the court with an unlimited discretion to rule out coercive measures when 'it is manifestly unfair'.

(c) it circumvents the major problem, already solved in France, of whether the sums due under a coercive measure should be added to those payable by way of damages or not.

(d) it states that the decision 'constitutes enforceable title' for the payment of sums due under coercive measure 'for any breach or next non-observance', before it is possible to say that the breach or non-observance will actually occur.

(e) finally, it states that the provision does not apply 'to the public and private employment controversies'. It is not clear though why the obligations of employers in public or private employment should enjoy such an exemption.

\section{Innovations on the right to be heard}

Article $101 \mathrm{CCP}$ has added a paragraph requiring the court to provide an opportunity to be heard to the parties, when it raises of its own motion a matter upon which it should make a decision.

This provision codifies trends in jurisprudence, repeats what was already contained in Art. 384, par. 3, CCP, for the proceeding before the Court of Cassation, and responds in a systemic way to Art. 183, paragraph 4, CCP. It orients the interpretation of the latter provision in the sense of putting an obligation on the court to provide an opportunity to be heard to the parties on the issues raised by the court on his motion in the first hearing..

\section{Codification of the principle of non- (non contestazione)}

The new wording of Art. 115, CCP, provides that the court shall base its decision 'on the facts which have not been specifically denied by the parties 1

A principle already accepted in practice is therefore codified, without however addressing the real problem of non-objection, which concerns the time limit within which objection is admissible as well as the conditions for the admissibility of a late objection. Moreover, the new text has failed to limit the principle of non-objection to disputes related to rights that can be waived (diritti disponibili).

3 S. Court of Cassation, Judgment no. 761 of 2002, in Foro It., 2002, I, 2019.

ZZPInt $14(2009)$ 
In terms of simplification and acceleration, with a little more courage it would have been possible to stipulate that, in disputes related to rights that can be waived, by the defendant counts as a legal admission of facts alleged by the plaintiff as the basis of the lawsuit and leads to a simplified decision (sentenza contumaciale). This is provided in several European jurisdictions (for example, in the Austrian, German and English, albeit with different nuances), and by Art. 663, CCP (eviction procecding).

\section{Introduction of a general norm on time limits (rimessione in termini)}

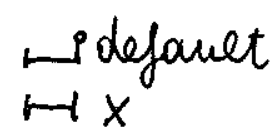

$\mapsto x$

Pextension

Art. 184-bis, CCP, has been repealed and its normative content has been moved to a second paragraph added to Art. 153, CCP.

The latter states now that the impossibility to extend the time limits may be set aside as a general rule if the party proves that the preclusion is due to a fortuitous event.

The then the rights of appeal, and to the power to resume or continue the interrupted or suspended process.

The legislator has failed to solve at least two problems.

First, a final time limit should be established, commencing on the day in which the fortuitous event ceased, within which the remission of the time limit should be requested.

An analogy, drawn from the regulation of the time limits to file an extraordinary appeal (Art. 326, CCP, revocazione straordinaria), points towards the establishment of a thirty-day period. For example, appeals should be filed within this period, combined together with the request of missiort (which request will then be directed to the court of appeal).

Second, it is necessary to establish an absolute time barrier beyond which it is no longer possible to apply for the regardless of the dissapearance of the impediment.

An analogy, drawn from the regulation of the 'long' term of appeal (Art. 327, $\mathrm{CCP}$ ), points to the provision of a six-month period, commencing on the expiration of the original time limit which was not observed.

9. Extension of the retroactivity of the 'rectification' of procedural defects

The new text of Art. 182, par. 2, CCP, provides for the retroactivity of the rectification in case of defect of representation, assistance or authorisation, or a defect which makes the power of attorney null, therefore, extending the principle of retroactivity of the rectification of procedural defects.

\section{Introduction of 'written testimony'}

Article 257-bis introduces written the parties agree and the judge regards it as appropriate 'considering the nature of the case and any other circumstance'.

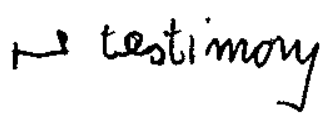


Caponi, Italian Civil Justice Reform 2009

The modification is loosely inspired by the regime of attestations of the French civil process, but it is doomed to have a marginal application, because the agreement of the parties is essential.

\section{1. 'Calendar' of the process}

The new Art. 81-bis of the rules on the implementation of the Code of Civil Procedure introduces a provision on the 'calendar' of the process: 'the court, when deciding on the evidentiary issues, after hearing the parties and taking into account the nature, urgency and complexity of the case, sets up the calendar of the process with an indication of subsequent hearings and requirements to be fulfilled. The dates scheduled on the calendar may be extended, even by the court of its own motion, when there are serious reasons that become known subsequently. The extension must be requested by the parties before the deadline'.

The norm may be of some use, not so much in order to allow the parties to anticipate the conclusion of their case, but rather in order to adjust the actual progress of the process to the complexity of the dispute in question, even if this timely adjustment, that responds to a standard of proportionality in the use of judicial resources, should face up to the excessive number of cases that the courts have on average to deal with which makes it difficult to model the length of the process on the peculiarities of a single case.

\section{Rationalisation and simplification of}

Article 54, Law 69 of 2009, authorises the Government to enact norms aimed at rationalising and simplifying the civil proceedings.

Within two years it should enact one or more legislative decrees, after which the special proceedings 'which fall within the ordinary jurisdiction and are regulated by special legislation' should be removed (with the exception of those regulated by bankruptcy laws, juvenile justice laws and a few others). All of these proceedings should be classified under one of the following three models:

(a) the model of labour disputes where there are 'prevailing features of concentration of the various procedural steps as well as of the proof taking by the Court of its own motion';

(b) the model of the aforementioned new summary proceeding, where there is a 'prevailing disposition towards the simplification of the treatment of the case';

(c) the model of the ordinary proceeding for all other cases.

The immediate repeal of the special proceeding for corporate cases (rito speciale societario, Legislative Decree no. 5 of 2003) is also stipulated, with the only exception of the special rules relating to arbitration.

The intention to reorganise and rationalise the myriad of special proceedings is certainly to be welcomed, except that the choice between three models (labour disputes, ordinary proceeding and summary proceeding) is characterised by traits of rigidity (accentuated by the impossibility to convert the summary proceeding into 
Caponi, Italian Civil Justice Reform 2009

the ordinary one). In fact, the first two proceedings always apply in the same identical way, regardless of the simplicity or complexity of the case that is at stake, while the summary proceeding is on the opposite extreme as it entrusts the judge with the control of the whole process.

A reorganisation of the proceedings that already exist should aim at - as already mentioned - expanding the ordinary process and differentiating within it two legislatively predetermined tracks, entrusted to the discretion of the court in collaboration with the parties, based on the complexity of the individual case.

\section{Reduction of the time}

A further modification is the reduction, not yet on the length of the process (because that goal is not within reach of a legislative reform), but on the time available to counsels to carry out certain procedural acts: the deadline for ordinary appeals is reduced from one year to six months (Art. 327, CCP), the deadlines to reinstate the action are reduced from six to three months (Arts. 50, 305, and 353, CCP), or from one year to three months (Art. 392, CCP).

The impact of the reform can be captured through an allegory (G. Balena): 'it is as if, to solve or alleviate the congestion on a stretch of a two-lane highway, on which travel is normally slow and stacked, instead of planning to build a third lane to make the traffic smoother (and thus faster), a prohibition or limitation on the time spent in the service areas is instructed'. By acting in such a way, the traffic already congested is clogged up further. Actually, the 'traffic of the cases' speeds up when a balanced relationship between number of cases and number of judges in charge of them is reached.

Due to pure forgetfulness, some of the terms for reinstatement of the action in six months (Art. 367, 627, 125-bis, 133-bis and ss.) remain unchanged.

\section{4. 'New' class action}

Article 49, Law no. 99, of $23^{\text {rd }}$ July 2009, on development and internationalisation of enterprises, as well as on energy (thus a different norm from Law no. 69 of 2009, which has been discussed so far) inspires the new version of Art. 140-bis, Consumer Code, in force since $1^{\text {st }}$ January 2010 . This appears as a reasonable improvement of the previous version.

The 'collective action for damages' is renamed as 'class action'. Actually, it might have been appropriate perhaps to keep the old name, which belongs to the Italian and European terminological tradition ('collective redress action') and better capture the nature of the action. In fact, the context in which it is introduced is different from that of American style class action, which thrives not so much from the sophisticated regulation of Rule 23 of the Federal Rules of Civil Procedure, but rather from the way of thinking of lawyers and judges who apply them, as well as the norms governing the funding of litigation costs ('contingency fees'). Instead, in the Italian legal 
Caponi, Italian Civil Justice Reform 2009

system any provision aimed at facilitating the funding of collective actions for damages is missing.

The matter of costs and professional fees is fully subject to the general rules, which since 2006 no longer ban agreements on contingency fees, i. e. allow the lawyer to negotiate with the client a fee commensurate with the result of the dispute.

The protection of 'homogeneous' individual rights in the civil proceeding requires a redefinition of the role of the legal profession, alongside that of consumer associations, as a possible factor of catalysis and unification. The effectiveness of the judicial remedies aimed at protecting homogeneous individual rights does not depend in fact solely on an appropriate design of the procedural regime, but also on the organisational skills of law firms, who know how to project themselves into this new dimension of the professional business. The ability of the judge to assess during the admissibility stage of the proceedings the 'healthy and robust composition' of the collective action also plays a central role.

The class action creates a new shape of joinder of parties, which was defined as 'aggregate' since it leads to an aggregation of serial actions (through the adesione) designed to claim 'homogeneous individual rights' of consumers or users against the respondent company.

The class action consists in the aggregation and joint management of the individual actions of the adhered members through a component of the class which can act alone or through associations, in order to assess liability and claim compensation for damages or restitutions.

The judgment in the collective process concerns the individual claims for compensation and restitution asserted by the adhered members, while 'the individual actions of those who do not adhere to the collective actions are admissible'.

In other words, the injured parties face a fundamental alternative: to pursue an individual or a collective lawsuit.

In both cases, the judgment is related to the individual claims for compensation and restitution.

In both cases, the decision power is on the individuals, who in the latter case can initiate the class action or adhere to that proposed by another party, an association or a committee.

The new instrument applies to cases of 'multi-offensive torts' (illeciti plurioffensi$v i)$ until now included in the regulation of joinder of parties:

(a) the contractual rights of a number of consumers and users who find themselves in the same situation in relation to the same company, including the rights relating to contracts concluded in accordance with Articles 1341 and 1342 of the Civil Code (general contract terms, forms);

(b) identical rights due to final consumers of a product in relation to its manufacturer, even in the absence of a direct contractual relationship;

(c) 'identical' rights to compensation for damages due to consumers and users and deriving from unfair commercial practices or anti-competitive behaviour.

The regulation grants standing to sue through class action to the single component of the class. This outcome marks the difference between the protection of homoge-

ZZPInt 14 (2009) 
Caponi, Italian Civil Justice Reform 2009

neous individual rights, which are the only ones explicitly dealt with by Art. 140-bis, and the protection of a supraindividual interest, understood as the interest of several people towards a good that has (also, or better, only) a dimension which is not susceptible of exclusive ownership and enjoyment.

Consumers and users who wish to avail of the protection under Art. 140-bis 'can join the class action'. Hence, the Italian system expresses its preference for the system in which the injured party must act if he wants to be included among the recipients of the result of the final judgment ('opt in'), rather than the opposite system-typical of some versions of the American class action- where all rights affected by the tort raised in court are substracted once and for all by the class representative, and the individual must act if he wants to be excluded from the list of recipients of the result of the judgement ('opt out').

The usefulness of adhesion is clear. Since we are not within the field of indivisible and joint obligations, Art. 1306, CC, does not apply. The person who did not join the lawsuit cannot take advantage of the effects of the favourable decision. The adhesion contract is then the document by which consumers or users may assert the decision granting the application against the company. The other side of the coin is the preclusion of any individual restitutory or remedial action based on the same title, as well as the subjection to the effects of the judgement rejecting the application.

The admissibility of the class action is subjected to a summary preliminary review, which culminates with a negative decision when the application is manifestly ungrounded, when there is a conflict of interest, when the court does not recognise the identity of the individual rights to be protected or when the claimant seems unable to adequately protect the interest of the class.

If the action is declared admissible, the Court sets the terms and methods of the most appropriate form of public notice of the action, so that those belonging to the class can join promptly. The court also 'determines the course of the procedure thereby ensuring, in accordance with the right to be heard, the fair, effective and prompt handling of the trial. In the same or subsequent order, which can be modified or revoked at any time, the court shall prescribe measures aimed at preventing undue repetitions or complications in the presentation of evidence or arguments; it burdens the parties with the form of notification which it considers necessary to protect the members; it regulates the evidentiary stage in the manner that it deems most appropriate and instructs any other procedural matter'.

Two possible alternatives of the content of the final decision are envisaged:

(a) a content of coercive relief, which will apply in all cases where the decision on liability of the defendant automatically leads to the determination of the amount to be recovered, or

(b) a content of declaration limited to the company's liability, where exceptionally there may be a need for an individualised decision that shall be advanced not in the collective process, but in a subsequent proceeding limited to the quantum or instead subject to inter-individual or collective negotiations.

The issue of determination of recoverable damages is one of the most delicate aspects of class action. The problem would require a legislative solution of substan- 
Caponi, Italian Civil Justice Reform 2009

tive law. The civil process cannot relinquish (at least de jure) the strict application of the substantive law, but it can adapt the latter regarding mass torts, so as to allow mechanisms of collective determination of damages (for example, as it happens with the American experience on 'fluid recovery').

The new wording of Art. 140-bis does not regulate (anymore) a second stage of the proceeding centred on the determination of the quantum.

The absence of this provision will not be missed, except in exceptional cases where the collective process concludes with a declaratory judgment on the liability of the company.

The law provides a spatium deliberandi in favour of the company. The decision becomes enforceable only after six months of its publication. Payments of amounts due which are done during this period are exempt from any increase. The aim is obviously to encourage voluntary compliance with the decision.

The individual action of those who do not opt in the collective action is admissible (even if the latter does not conclude with a ruling on the merits), but it is not possible to bring further class actions on the same acts and against the same company after the deadline for joining assigned by the court in the decision on admissibility. The actions brought within this period are combined by the court of its own motion, if pending before the same court. If the second action is brought before another court, the removal of the lawsuit from the register is ordered, and a peremptory time limit not exceeding sixty days for readmission before the first court is issued.

To sum up, the class action can perform a variety of functions. First, it fullfils the guarantee of access to justice in the case of small claims. The advantages of this instrument make it preferred not only to traditional serial actions, but also to individual mediation proceedings.

In case of mass damage (because the injured parties are many, if the individual harm is so slight that it is not worth claiming it before the court, and not even putting it on the basis of a mediation proceeding, the aggregation of the homogeneous individual claims by a class representative, as stated by Art. 140-bis, cuts costs and therefore constitutes the cornerstone of a judicial response aimed at removing the reasons why consumers and users relinquish their right to assert their claims before the courts.

In this case, the new instrument does not serve the purpose of procedural economy and efficiency. But it allows bringing out latent disputes, that would not otherwise emerge before the courts due to the disproportionality between the value of a single case, typically modest, and the costs of the individual plea before the courts or of the mediation proceedings.

In this last respect, the class action works a little like a 'vacuum cleaner' regarding mediation proceedings, freeing the latter from the 'dust' of low-value serial controversies (in which there can then only be space for a positional negotiation of large scale), freeing resources for the efforts to reach individualised mediation (or for the efforts of a collective mediation after bringing a class action) and thus enhancing the professional competence and the work of the mediator.

In other words, the introduction of the class action is a fundamental element of a strategy to improve the conditions of the civil justice system in the field of consu- 
Caponi, Italian Civil Justice Reform 2009

mers' protection. This is aimed therefore at preventing the alternative methods of dispute resolution from turning into a way to provide an inadequate response to a demand for justice frustrated due to the lack of an efficient alternative to the civil justice system.

In addition to providing individual relief to injured parties, the new instrument also provides - as a second feature - a deterrent to the commission of harmful illegal acts against a relatively broad range of consumers.

The class action organises a collective reaction by the consumers against the company's mass tort. The action then displays a deterrent effect on the latter, that the individual reaction of consumers before the court or the mediation bodies certainly cannot have.

In this area, the private judicial initiative of the consumers (private enforcement) supports the public effort of prevention and control of the economic power of the company, as a sort of counterpower that emerges from the society, as opposed to the economic power of the company.

In this sense, the Italian civil process (like that of other European countries that have introduced collective redress actions) is enriched with a new function, traditionally entrusted to the state and the public administration in continental Europe: the function of regulation and control of social and economic behaviour that impact not so much on the interests of an isolated individual, but on the interests of a community.

Third, restitutory class actions meet the goal of procedural economy and efficiency in disputes that would otherwise be commended to ordinary multi-party litigation.

\section{References}

G. Balena, R. Caponi, A. Chizzini, S. Menchini, La riforma del processo civile Commento alle disposizioni della legge sul processo civile n. 69/2009, Torino, Utet, 2009, p. 1-273. 